CLINICAL STUDY

\title{
Remission criteria for the follow-up of patients with acromegaly
}

\author{
Sevim Gullu, Hatice Keles ${ }^{1}$, Tuncay Delibasi, Vedia Tonyukuk, Nuri Kamel and Gurbuz Erdogan \\ Department of Endocrinology and Metabolic Diseases, School of Medicine, Ankara University, 06100 Ankara, Turkey and ${ }^{1}$ Department of Internal \\ Medicine, Faculty of Medicine, Kirikkale University, 71100 Kirikkale, Turkey \\ (Correspondence should be addressed to S Gullu, Department of Endocrinology and Metabolic Diseases, School of Medicine, Ankara University, \\ Ibn-i Sina Hospital, 10th Floor, D-block, 06100 Sihhiye-Ankara, Turkey; Email: sevim.gullu@temd.org.tr)
}

\begin{abstract}
Objective: The aim was to evaluate the validity of current remission criteria in acromegaly, a random GH level of $<2.5 \mu \mathrm{g} / \mathrm{l}$, a glucose-suppressed GH level of $<1 \mu \mathrm{g} / \mathrm{l}$ and a normal IGF-I level.

Design: In forty-one patients treated for acromegaly (23 males and 18 females, 20-69 years) and 94 healthy subjects (50 males and 44 females, 20-78 years), basal GH and IGF-I levels and nadir GH levels after $75 \mathrm{~g}$ oral glucose were evaluated in decade blocks; these were assayed by sensitive immunoradiometric assays.

Results: Basal GH levels varied widely from 0.022 to 10.4 in healthy subjects and were $>2.5 \mu \mathrm{g} / \mathrm{l}$ in $19 \%$. The mean post-glucose GH nadir was $0.067 \pm 0.009 \mu \mathrm{g} / \mathrm{l}$ (range $0.003-0.4 \mu \mathrm{g} / \mathrm{l}$ ) and the upper limit of the GH nadir was $0.26 \mu \mathrm{g} / \mathrm{l}$ (means +2 s.D.) in healthy subjects. Thirty-five patients with acromegaly had high-for-age IGF-I levels in relation to our healthy subjects. In this group, 15 $(42.9 \%)$ patients had basal GH levels of $<2.5 \mu \mathrm{g} / \mathrm{l}, 14(40 \%)$ patients had nadir $\mathrm{GH}$ levels of $<1 \mu \mathrm{g} / \mathrm{l}$, and three $(8.6 \%)$ patients had GH suppression to $<0.26 \mu \mathrm{g} / \mathrm{l}$ which was defined as normal GH suppression in our healthy subjects. Only six patients with acromegaly had normal-forage IGF-I levels and all of these patients had basal GH levels of $<2.5 \mu \mathrm{g} / \mathrm{l}$ and all but one had nadir $\mathrm{GH}$ levels of $<0.26 \mu \mathrm{g} / \mathrm{l}$.

Conclusions: A basal or random GH level of $<2.5 \mu \mathrm{g} / \mathrm{l}$ is not a reliable criterion for remission in acromegaly and the currently accepted normal upper limit of $1 \mu \mathrm{g} / \mathrm{l}$ for post-glucose $\mathrm{GH}$ suppression is too high. Post-glucose nadir GH levels, measured with sensitive assays, can be $<1.0 \mu \mathrm{g} / \mathrm{l}$ in $40 \%$ and basal GH levels can be $<2.5 \mu \mathrm{g} / \mathrm{l}$ in $43 \%$ of the active acromegalic patients. IGF-I levels appeared to correlate better with a nadir GH cut-off of $0.26 \mu \mathrm{g} / \mathrm{l}$ rather than $1 \mu \mathrm{g} / \mathrm{l}$ in the determination of disease activity.
\end{abstract}

European Journal of Endocrinology 150 465-471

\section{Introduction}

Acromegaly is a severe slow developing disease caused by growth hormone $(\mathrm{GH})$ hypersecretion resulting almost invariably from a pituitary adenoma (1). $\mathrm{GH}$-based criteria, random or basal $\mathrm{GH}$ values and glucose-suppressed GH levels, and insulin-like growth factor-I (IGF-I) levels are the most widely used biochemical parameters, in contrast to the mean integrated 24-h GH level which is neither practical nor cost-effective, for the diagnosis and follow-up of acromegalic patients $(2-7)$. The accepted normal cut-off limits for basal and glucose-suppressed $\mathrm{GH}$ levels in both healthy subjects and in patients with acromegaly have changed over the years due to the improved sensitivity and specifity of $\mathrm{GH}$ assays as well as the availability of accurate IGF-I measurements (8-13). Currently, GH suppression after an oral glucose tolerance test (OGTT) to less than $1 \mu \mathrm{g} / \mathrm{l}$ with sensitive assays and IGF-I levels reduced to the age-adjusted normal range are recommended for the decision of remission, and basal GH values less than $2.5 \mu \mathrm{g} / \mathrm{l}$ have been suggested to be safe biochemical parameters for the control of acromegaly $(13-16)$. However, some evidence in healthy subjects and acromegalic patients, using highly sensitive assays, has recently suggested that the cut-off value for the $\mathrm{GH}$ nadir after oral glucose administration is much lower than $1.0 \mu \mathrm{g} / \mathrm{l}(17-20)$. Thus, there is a need for the re-appraisal of normal GH suppression criteria and revision of the consensus statement. We therefore evaluated basal and glucose-suppressed GH levels in conjunction with IGF-I levels in 94 healthy subjects and 41 patients treated for acromegaly, using sensitive assays, in order to determine the basal and post-glucose nadir GH levels in normal subjects and whether they can be useful in evaluating the disease status of patients with acromegaly.

\section{Subjects and methods}

\section{Normal subjects}

The study included 94 healthy adult subjects (50 men and 44 women, mean age $42.6 \pm 1.5$ years; range, 
20-78 years) who were selected based on their health status. They had no endocrine, renal or hepatic disease, were taking no medications (including oral contraceptives) and were within $10 \%$ of ideal body weight. The mean body mass index (BMI) of the healthy subjects was $23.1 \pm 0.2 \mathrm{~kg} / \mathrm{m}^{2}$. Premenopausal women were studied in the early follicular phase of the menstrual cycle (days 1-5).

\section{Treated acromegalic patients}

From a cohort of 86 acromegalic patients, who have been followed-up in our outpatient clinics, we studied 41 patients (23 men and 18 women, mean age $46.7 \pm 2.1$ years; range, 20-69 years) who had previously been submitted to different treatment modalities (surgery and/or radiotherapy) at various times before the study. Acromegalic patients who had any other endocrine disease, including diabetes mellitus, glucose intolerance and hypopituitarism, and active hepatic or renal disease were not included in the study. Five patients were treated with both surgery and radiotherapy, and two patients were treated only with radiotherapy. All operated patients were studied for at least 6 months after surgery, with a mean period from surgery to evaluation of 6.6 years (range, 6 months to 34 years). Seven patients had undergone radiotherapy from 1 to 9 years before testing. Fourteen patients had been treated with bromocriptine and/or octreotide in the past but neither GH-suppressive medication had been taken for at least 3 months in any of these subjects. The mean BMI of the patients was $30.4 \pm 0.8 \mathrm{~kg} / \mathrm{m}^{2}$.

\section{Study procedures}

After an overnight fast for $10 \mathrm{~h}$, all subjects underwent an OGTT. They came to the dynamic test unit at 0730 , had an i.v. cannula inserted into a forearm vein, and then remained seated from $0800 \mathrm{~h}$ until the end of the test. Blood samples for $\mathrm{GH}$ and glucose measurements were collected through the cannula at -30 and $0 \mathrm{~min}$ and then 30,60,90 and $120 \mathrm{~min}$ after drinking $75 \mathrm{~g}$ glucose in $300 \mathrm{ml}$ lemon-flavoured water. After the separation of serum at each time point, glucose levels were measured and then the serum was frozen at $-80^{\circ} \mathrm{C}$ in multiple aliquots. According to WHO criteria, subjects were considerd to be normal with a basal serum glucose level less than $126 \mathrm{mg} / \mathrm{dl}$ and a 2-h post-glucose level less than $200 \mathrm{mg} / \mathrm{dl}$. This protocol was approved by the University Hospital Ethics Committee and informed written consent was obtained from all subjects.

\section{Assays}

Plasma glucose concentrations were measured by the glucose oxidase method using an autoanalyzer. GH was measured all together and in duplicate by a highly sensitive immunoradiometric assay (IRMA) obtained from BIOCODE S.A. (Liège, Belgium). The standards contained $22 \mathrm{kDa}$ recombinant human $\mathrm{GH}$ and were calibrated to the first WHO International Reference Preparation of human GH (code 88/624). The intra- and interassay coefficients of variation were 3.2 and $5.2 \%$ respectively. The assay sensitivity in our laboratory is $0.003 \mu \mathrm{g} / \mathrm{l}$. Plasma IGF-I levels were determined all together and in duplicate by an active non-extraction IRMA obtained from Diagnostic Systems Laboratories, Inc. (Webster, TX, USA). The standards contained recombinant human IGF-I and were calibrated to the WHO International Reference Reagent for IGF-I for immunoassay (code 87/518). The intra- and interassay coefficients of variation were 7 and $7.4 \%$ respectively. The minimum detectable amount of IGF-I was $2.06 \mathrm{ng} / \mathrm{ml}$.

\section{Statistical analysis}

The baseline glucose level was defined as the average of plasma glucose levels at two time points before ingestion of glucose, and the peak glucose level was defined as the highest value at any time point after oral glucose administration. The random or basal GH level was defined as the average of $\mathrm{GH}$ levels at two time points before ingestion of glucose, and the nadir $\mathrm{GH}$ level was defined as the lowest value at any time point after oral glucose administration. The upper limit of the normal nadir $\mathrm{GH}$ was defined as the $\mathrm{GH}$ value 2 S.D. above the mean nadir of the healthy subjects. Since serum GH levels were not normally distributed, non-parametric tests, Wilcoxon-Mann-Witney tests for comparisons and Spearman correlation tests were used where appropriate for statistical analysis. The relationship between IGF-I and age was compared by regression analysis. Statistical significance was assumed at $P<0.05$. The data are expressed as the mean \pm s.E.

\section{Results}

\section{Healthy subjects}

There were no significant differences between male and female subjects in basal or post-glucose peak plasma glucose levels. $\mathrm{GH}$ levels in $16 \%$ of all serum samples were below the sensitivity of the assay and $83 \%$ of these were from the nadir GH serum samples. Basal $\mathrm{GH}$ values varied widely, from 0.022 to $10.4 \mu \mathrm{g} / \mathrm{l}$, and the mean value was significantly higher in women than in men $(2.02 \pm 0.34$ vs $0.68 \pm 0.18 \mu \mathrm{g} / \mathrm{l}$, $P<0.001)$. Basal GH levels were above $2.5 \mu \mathrm{g} / \mathrm{l}$ in $19 \%$ (18 of 94 ) of healthy subjects. In all healthy subjects, the mean decline from basal GH concentrations was $84 \pm 4 \%$, and this decrease was significantly greater in women than in men $(86 \pm 6 \%$ vs $82 \pm 5 \%$; 
mean ranks 57.3 vs $38.9, P=0.001)$. The mean GH nadir of healthy subjects was $0.067 \pm 0.009 \mu \mathrm{g} / \mathrm{l}$ with a range of $0.003-0.4 \mu \mathrm{g} / \mathrm{l}$. Female subjects had significantly higher $\mathrm{GH}$ nadir values than men $(0.087 \pm 0.02$ vs $0.051 \pm 0.01 \mu \mathrm{g} / \mathrm{l}, P<0.05)$. The upper limit of normal GH nadir values, defined as the value of 2 S.D. above the mean nadir of healthy subjects, was $0.26 \mu \mathrm{g} / \mathrm{l}$. This value was higher in women than in men $(0.31$ vs $0.2 \mu \mathrm{g} / \mathrm{l})$. There were no significant correlations between $\mathrm{GH}$ nadir concentrations and peak plasma glucose, BMI or age. However, there was a strong correlation between basal and nadir GH levels $(r=0.613, P<0.001)$. Healthy subjects were subgrouped in decades, each including between nine and eleven males and seven and eleven females. Table 1 shows basal GH and IGF-I levels, and nadir GH levels with the upper limit of normal defined by means +2 S.D. in each sex and age group. Basal and nadir GH levels did not show any significant difference between the age groups. This was also true for male and female age groups. Nadir GH levels showed a significant gender difference, higher in females than in males, only in the 20- to 29-year-old age group $(P<0.05$, Table 1). Six healthy subjects (five female, one male) had nadir GH levels above $0.26 \mu \mathrm{g} / \mathrm{l}$. Among these, three female subjects were in the third decade and their nadir GH levels were less than the calculated cut-off level for this age group $(0.47 \mu \mathrm{g} / \mathrm{l})$. Another three subjects were in the fifth and sixth decades and had nadir $\mathrm{GH}$ levels that were also higher than the calculated cut-off levels for corresponding age groups. The mean IGF-I level in healthy subjects was $220 \pm 10 \mathrm{ng} / \mathrm{ml}$ (range, 39-462 ng/ml), and there was no gender difference. IGF-I levels correlated with neither basal nor nadir GH levels but showed strong negative correlation with age $(r=-0.714$,
$P<0.001)$. The equation for the regression line was: IGF-I $(\mathrm{ng} / \mathrm{ml})=412-4.56 \times$ age $($ year $)$. The agedependent reference range (means \pm 2 S.D.) for IGF-I in healthy subjects is shown in Table 2 .

\section{Subjects with acromegaly}

Table 3 shows the distribution of patients with treated acromegaly based on current and newly proposed $\mathrm{GH}$ criteria for remission as a function of IGF-I being normal or high.

\section{Basal GH level as a criterion for acromegaly remission}

Based on the basal GH cut-off value of $2.5 \mu \mathrm{g} / \mathrm{l}$, acromegalic patients were divided into two groups: an active group including those with basal GH levels above $2.5 \mu \mathrm{g} / \mathrm{l}$ and a remission group including those with basal GH levels less than $2.5 \mu \mathrm{g} / \mathrm{l}$. Basal GH levels were less than $2.5 \mu \mathrm{g} / \mathrm{l}$ in $51 \%$ (21 of 41 ) of all acromegalic patients. Fifteen of these patients $(71.4 \%)$ had high age-adjusted IGF-I levels in relation to our healthy subjects, and only six $(28.6 \%)$ had normal IGF-I levels. Of the patients with basal GH levels of less than $2.5 \mu \mathrm{g} / \mathrm{l}$, only eight (38.1\%) had post-glucose nadir GH levels of $<0.26 \mu \mathrm{g} / \mathrm{l}$ and five of these were the ones with normal IGF-I levels.

\section{GH nadir as a criterion for acromegaly remission}

Based on the normal post-glucose nadir GH cut-off value of $1 \mu \mathrm{g} / \mathrm{l}$, all treated acromegalic patients were divided into an active group including those with nadir $\mathrm{GH}$ levels above $1 \mu \mathrm{g} / \mathrm{l}$ and a remission group

Table 1 Basal GH and nadir GH levels with the upper limit of normal and basal IGF-I levels in each age and sex group of healthy subjects.

\begin{tabular}{|c|c|c|c|c|c|}
\hline \multirow{2}{*}{$\begin{array}{l}\text { Age groups } \\
\text { (years) }\end{array}$} & \multirow{2}{*}{$\begin{array}{l}\text { Gender } \\
(n)\end{array}$} & \multirow{2}{*}{$\begin{array}{c}\text { Basal GH }(\mu \mathrm{g} / \mathrm{l}) \\
(\text { mean } \pm \text { S.E. })\end{array}$} & \multicolumn{2}{|c|}{ Nadir GH $(\mu \mathrm{g} / \mathrm{l})$} & \multirow{2}{*}{ 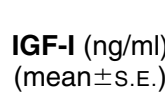 } \\
\hline & & & (mean \pm S.E. $)$ & (mean \pm 2 s.D.) & \\
\hline \multirow[t]{3}{*}{$20-29$} & $F(11)$ & $3.29 \pm 0.97^{*}$ & $0.17 \pm 0.04^{\star}$ & $0.47^{\star}$ & $305 \pm 20$ \\
\hline & $M(11)$ & $1.13 \pm 0.45^{\star}$ & $0.05 \pm 0.02^{*}$ & $0.2^{*}$ & $325 \pm 24$ \\
\hline & $\mathrm{T}(22)$ & $2.21 \pm 0.57$ & $0.11 \pm 0.03$ & 0.37 & $315 \pm 15$ \\
\hline \multirow[t]{3}{*}{$30-39$} & $F(10)$ & $1.75 \pm 0.55^{\star}$ & $0.02 \pm 0.01$ & 0.07 & $269 \pm 24$ \\
\hline & $M(10)$ & $0.07 \pm 0.02^{*}$ & $0.01 \pm 0.03$ & 0.07 & $238 \pm 21$ \\
\hline & $\mathrm{T}(20)$ & $0.91 \pm 0.33$ & $0.02 \pm 0.01$ & 0.07 & $256 \pm 16$ \\
\hline \multirow[t]{3}{*}{$40-49$} & $F(9)$ & $2.68 \pm 0.73^{*}$ & $0.07 \pm 0.03$ & 0.26 & $207 \pm 17$ \\
\hline & $M(10)$ & $0.87 \pm 0.50 *$ & $0.07 \pm 0.03$ & 0.26 & $189 \pm 21$ \\
\hline & $\mathrm{T}(19)$ & $1.73 \pm 0.48$ & $0.07 \pm 0.02$ & 0.26 & $198 \pm 14$ \\
\hline \multirow[t]{3}{*}{$50-59$} & $F(7)$ & $0.88 \pm 0.34^{\star}$ & $0.08 \pm 0.04$ & 0.27 & $135 \pm 28$ \\
\hline & $\mathrm{M}(9)$ & $0.74 \pm 0.63^{*}$ & $0.05 \pm 0.02$ & 0.18 & $168 \pm 18$ \\
\hline & $\mathrm{T}(16)$ & $0.80 \pm 0.37$ & $0.06 \pm 0.02$ & 0.22 & $153 \pm 16$ \\
\hline \multirow[t]{3}{*}{60 and over } & $F(7)$ & $0.68 \pm 0.25$ & $0.08 \pm 0.03$ & 0.18 & $128 \pm 24$ \\
\hline & $M(10)$ & $0.57 \pm 0.19$ & $0.07 \pm 0.03$ & 0.25 & $138 \pm 21$ \\
\hline & $\mathrm{T}(17)$ & $0.61 \pm 0.15$ & $0.08 \pm 0.02$ & 0.24 & $135 \pm 16$ \\
\hline
\end{tabular}

* Gender difference is significant at $P<0.05$ (Mann-Witney).

$\mathrm{F}$, female; $\mathrm{M}$, male; $\mathrm{T}$, total. 
Table 2 Reference values of serum IGF-I concentrations in relation to age in healthy subjects.

\begin{tabular}{lcccc}
\hline & & \multicolumn{3}{c}{ IGF-I (ng/ml) } \\
\cline { 3 - 5 } $\begin{array}{l}\text { Age } \\
\text { years) }\end{array}$ & $\begin{array}{c}\text { Number } \\
\text { (male/female) }\end{array}$ & -2 S.D. & Mean & +2 S.D. \\
\hline $20-29$ & $22(11 / 11)$ & 171 & 315 & 459 \\
$30-39$ & $20(10 / 10)$ & 112 & 254 & 396 \\
$40-49$ & $19(10 / 9)$ & 78 & 198 & 318 \\
$50-59$ & $16(9 / 7)$ & 27 & 153 & 279 \\
60 and over & $17(10 / 7)$ & 13 & 135 & 257 \\
\hline
\end{tabular}

Table 3 Distribution of patients with treated acromegaly based on current and newly proposed $\mathrm{GH}$ criteria for remission as a function of IGF-I being normal or high.

\begin{tabular}{|c|c|c|c|c|}
\hline & \multicolumn{2}{|c|}{$\begin{array}{l}\text { Normal } \\
\text { IGF-I }\end{array}$} & \multicolumn{2}{|c|}{ High IGF-I } \\
\hline & $n$ & $\%$ & $n$ & $\%$ \\
\hline Basal GH $<2.5 \mu \mathrm{g} / \mathrm{l}(n=21)$ & 6 & 28.6 & 15 & 71.4 \\
\hline Basal GH $>2.5 \mu \mathrm{g} / \mathrm{l}(n=20)$ & 0 & 0 & 20 & 100 \\
\hline Nadir $\mathrm{GH}<1 \mu \mathrm{g} / \mathrm{I}(n=20)$ & 6 & 30 & 14 & 70 \\
\hline Nadir $\mathrm{GH}>1 \mu \mathrm{g} / \mathrm{l}(n=21)$ & 0 & 0 & 21 & 100 \\
\hline Nadir GH $<0.26 \mu \mathrm{g} / \mathrm{l}(n=8)$ & 5 & 62.5 & 3 & 37.5 \\
\hline Nadir GH $>0.26 \mu \mathrm{g} / \mathrm{l}(n=33)$ & 1 & 3 & 32 & 97 \\
\hline
\end{tabular}

including those with nadir GH levels less than $1 \mu \mathrm{g} / \mathrm{l}$. There were $20(48.8 \%)$ patients in the remission group and $21(51.3 \%)$ patients in the active group. No patient in the active group had normal IGF-I levels and all but two had basal GH levels above $2.5 \mu \mathrm{g} / \mathrm{l}$. However, in the remission group, $14(70 \%)$ patients had high IGF-I levels and $17(85 \%)$ patients had basal GH levels of less than $2.5 \mu \mathrm{g} / \mathrm{l}$.

When we adopted the GH nadir limit of $0.26 \mu \mathrm{g} / \mathrm{l}$, derived from our healthy subjects, there were 33 patients $(80.5 \%)$ in the active group and only eight patients $(19.5 \%)$ in the remission group. In the active group, 97\% (32 of 33) of patients had concordance of nadir GH over $0.26 \mu \mathrm{g} / \mathrm{l}$ with elevated IGF-I levels. All the patients in the remission group had basal $\mathrm{GH}$ levels less than $2.5 \mu \mathrm{g} / \mathrm{l}$ and five had normal ageadjusted IGF-I levels while another three had elevated age-adjusted IGF-I levels.

\section{IGF-I level as a criterion for acromegaly remission}

All patients with acromegaly were divided into two groups based on their IGF-I levels for age in relation to ranges defined in our healthy subjects. The first group contained the subjects with high-for-age IGF-I levels and the second one contained subjects with normal-for-age IGF-I levels. Table 4 shows basal GH and IGF-I levels and nadir GH levels after OGTT in these two groups of patients and in healthy subjects.
Table 4 Basal GH and IGF-I levels and post-glucose nadir GH levels in healthy subjects and in subjects with acromegaly with normal and high-for-age IFG-I levels. Values are means \pm S.E. with ranges in parentheses.

\begin{tabular}{ccccc}
\hline & Healthy subjects & & \multicolumn{2}{c}{ Patients with acromegaly } \\
\cline { 2 - 3 } \cline { 5 - 6 } & $(n=94)$ & & $\begin{array}{c}\text { High IGF-I } \\
(n=35)\end{array}$ & $\begin{array}{c}\text { Normal IGF-I } \\
(n=6)\end{array}$ \\
\hline Basal GH $(\mu \mathrm{g} / \mathrm{l})$ & $1.31 \pm 0.2$ & & $8.39 \pm 2.5$ & $0.46 \pm 0.29$ \\
& $(0.022-10.4)$ & & $(0.18-68.8)$ & $(0.07-1.9)$ \\
Nadir GH $(\mu \mathrm{g} / \mathrm{l})$ & $0.068 \pm 0.01$ & & $4.84 \pm 1.26$ & $0.15 \pm 0.04$ \\
& $(0.003-0.4)$ & & $(0.15-30.6)$ & $(0.02-0.3)$ \\
IGF-I $(\mathrm{ng} / \mathrm{ml})$ & $220 \pm 10$ & & $831 \pm 81$ & $143 \pm 41$ \\
& $(39-462)$ & & $(261-2000)$ & $(30-331)$ \\
\hline
\end{tabular}

\section{Subjects with acromegaly with elevated IGF-I levels}

Thirty-five subjects with acromegaly had elevated IGF-I levels for age. Basal GH levels were less than $2.5 \mu \mathrm{g} / \mathrm{l}$ in $42.9 \%$ (15 of 35 ) of these patients. The $\mathrm{GH}$ nadir failed to be suppressed to the normal range, as defined by our healthy subjects, in 32 of these patients. In $40 \%$ (14 of 35) of the active group, nadir GH levels were less than $1 \mu \mathrm{g} / \mathrm{l}$, between 0.15 and $0.99 \mu \mathrm{g} / \mathrm{l}$, a GH nadir previously considered normal by strict criteria. Three of these 14 patients had normal GH suppression, defined by our healthy subjects, after oral glucose, the nadir GH being $0.15,0.22$ and $0.23 \mu \mathrm{g} / \mathrm{l}$.

\section{Subjects with acromegaly with normal IGF-I levels}

Six patients operated for acromegaly showed normalfor-age IGF-I. All of these patients had basal GH levels less than $2.5 \mu \mathrm{g} / \mathrm{l}$. The mean nadir $\mathrm{GH}$ in this group was significantly lower than that in the high IGF-I group $(P<0.001)$ and was significantly higher than that in healthy subjects $(P<0.01)$ (Table 3$)$. The nadir $\mathrm{GH}$ range in this group was $0.02-0.3 \mu \mathrm{g} / \mathrm{l}$, and the majority of subjects (five of six) had nadir $\mathrm{GH}$ values that fell within the normal range defined by our healthy subjects (i.e. $<0.26 \mu \mathrm{g} / \mathrm{l}$ ). One remaining patient, who had an IGF-I level of $30 \mathrm{ng} / \mathrm{ml}$, had GH suppression to $0.3 \mu \mathrm{g} / \mathrm{l}$, which was above $0.26 \mu \mathrm{g} / \mathrm{l}$, but lower than the maximum nadir $\mathrm{GH}$ level, which was $0.4 \mu \mathrm{g} / \mathrm{l}$, observed in our healthy subjects.

There was no gender difference in basal GH, nadir GH and IGF-I levels in acromegalic patients with high IGF-I levels. Basal GH levels correlated significantly with nadir GH levels in all acromegalic patients $(r=0.853, P<0.001)$. This was the case for both the high IGF-I group $(r=0.791, P<0.001)$ and the normal IGF-I group $(r=0.948, P<0.01)$. There were no correlations of basal $\mathrm{GH}$ and nadir $\mathrm{GH}$ levels with age or BMI in acromegalic subjects. IGF-I levels 
correlated negatively with age $(r=-0.333, P=$ 0.034 ) but not with BMI in acromegalic subjects.

Figure 1 illustrates nadir GH values in the different groups of subjects. In healthy subjects and in patients with normal IGF-I levels, neither basal nor nadir GH levels correlated with IGF-I levels. In patients with high IGF-I levels both basal and nadir GH levels correlated significantly with IGF-I levels $(r=0.397$, $P=0.018$ and $r=0.450, P=0.007$ respectively).

\section{Discussion}

Since even minimal biochemical activity of acromegaly can be associated with the full-blown severe clinical syndrome and, when inadequately treated, persistent excess GH secretion is associated with increased morbidity and mortality, aggressive control of $\mathrm{GH}$ and IGF-I levels as tightly as possible is necessary (2027). Residual disease activity is most widely evaluated by biochemical tests; however, the definition of remission for acromegaly is controversial. The issue is whether we should attain normalized $\mathrm{GH}$ responses and levels or safe levels. Some define remission as a random GH level less than $2.5 \mu \mathrm{g} / \mathrm{l}$ and an OGTTderived $\mathrm{GH}$ level less than $2 \mu \mathrm{g} / \mathrm{l}$ measured by RIA and/or normalization of the IGF-I level, by using the data obtained from epidemiological studies $(14,16$, 22-25). Most endocrinologists use the biochemical definition of remission in acromegaly as a glucose-suppressed GH level of $<1 \mu \mathrm{g} / \mathrm{l}$ measured with a sensitive assay and a normal age-related IGF-I level (12, 13, 27). However, studies to date do not provide a robust definition of biochemical remission of the

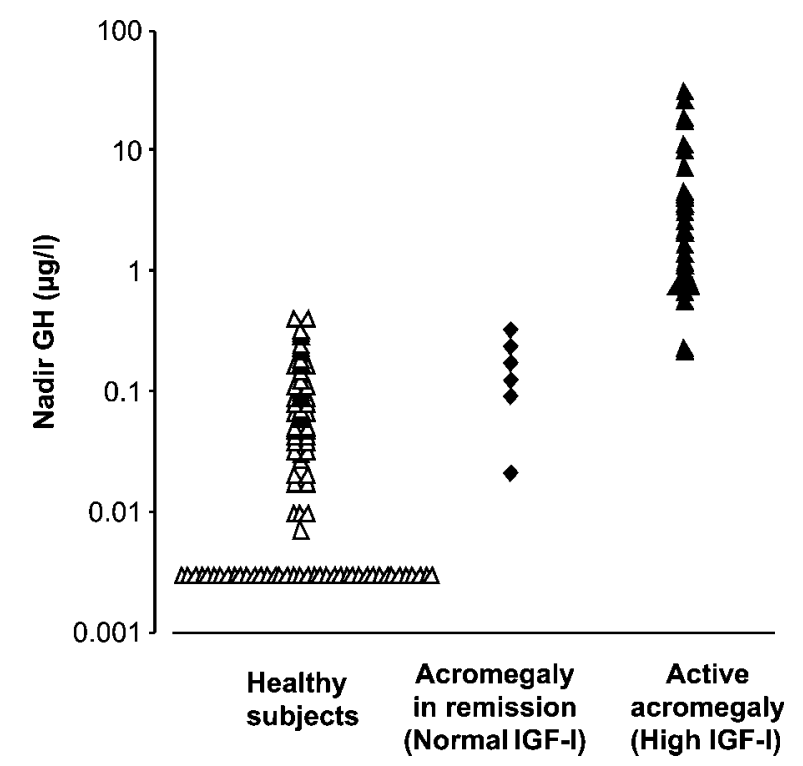

Figure 1 Nadir $\mathrm{GH}$ values after a $75 \mathrm{~g}$ OGTT in healthy subjects $(\triangle)$ and in treated acromegalic patients with a normal IGF-I level $(\boldsymbol{\Lambda}$, remission) and a raised IGF-I level $(\diamond$, active disease). Note the logarithmic scale for $\mathrm{GH}$. disease based on correlation with the long-term outcome (16).

In our opinion, basal GH level is not a reliable criterion for the disease activity of acromegaly, since $\mathrm{GH}$ secretion is pulsatile and varies over a wide range. In the present study, although a basal GH cut-off value of $2.5 \mu \mathrm{g} / \mathrm{l}$ seems to be a good predictor of high IGF-I level in acromegalic patients, $19 \%$ of normal subjects had basal GH level of $>2.5 \mu \mathrm{g} / \mathrm{l}$ and could not be regarded as acromegalic. Furthermore, $43 \%$ of acromegalic patients with high IGF-I levels had basal GH values of $<2.5 \mu \mathrm{g} / \mathrm{l}$ and could not be regarded as being in remission. It is obvious that discrepant $\mathrm{GH}$ and IGF-I values can be seen in acromegalic patients.

With OGTT, older criteria defined remission in acromegaly as a suppression of GH to less than $2 \mu \mathrm{g} / \mathrm{l}$ as measured by assays with limited sensitivity $(8-10)$. With the development of more sensitive GH assays, it has been suggested that $\mathrm{GH}$ should be suppressed to less than $1 \mu \mathrm{g} / \mathrm{l}$ after oral glucose for the decision of remission (13). In the present study, the highest glucose-suppressed GH level measured by a sensitive IRMA was $0.4 \mu \mathrm{g} / \mathrm{l}$ and the calculated nadir GH cutoff value was $0.26 \mu \mathrm{g} / \mathrm{l}$ in all healthy subjects. In the patients with clinically and radiologically active acromegaly, GH was suppressed as low as $0.15 \mu \mathrm{g} / \mathrm{l}$, in three patients overlapping with the normal range defined in our healthy subjects and, in $40 \%$ (14 of 35 ) of these patients, nadir GH levels were less than $1 \mu \mathrm{g} / \mathrm{l}$. In the inactive group, all patients but one had a normal GH suppression and, in the patient with an abnormal suppression, the GH nadir was $0.3 \mu \mathrm{g} / \mathrm{l}$, i.e. over the defined cut-off value $(0.26 \mu \mathrm{g} / \mathrm{l})$ but lower than the maximum value $(0.4 \mu \mathrm{g} / \mathrm{l})$ obtained in our healthy subjects. If we adopt the GH nadir limit of $1 \mu \mathrm{g} / \mathrm{l}$, the currently accepted criterion, $48.8 \%$ of all treated patients (20 of 41 ) and $40 \%$ of the treated acromegalic patients with high IGF-1 levels (14 of 35) would be considered to be in remission. This means that a cut-off of $1 \mu \mathrm{g} / \mathrm{l}$ will fail to identify $40 \%$ of patients with active disease. Using a sensitive $\mathrm{GH}$ assay, the cut-off of the $\mathrm{GH}$ nadir less than $0.26 \mu \mathrm{g} / \mathrm{l}$ is more closely related to normal age-appropriate IGFI levels and disease activity in treated acromegalic patients. Our findings show that the post-glucose $\mathrm{GH}$ nadir is lower than previously believed in healthy subjects and suggest a lower cut-off value.

Recently, with the availability of highly sensitive assays for GH and accurate IGF-I measurements, new cut-off values have also been suggested by others (17-20). Previously Hattori et al. (17) reported a median nadir $\mathrm{GH}$ level after oral glucose ingestion as $0.15 \mu \mathrm{g} / \mathrm{l}(0.047-1.3 \mu \mathrm{g} / \mathrm{l})$ in healthy adults, using an enzymeimmunoassay (17). Later Chapman et al. (18) reported normal GH response to glucose, using an ultrasensitive chemiluminescence assay, as suppression below $0.5 \mu \mathrm{g} / \mathrm{l}$ (means +2 s.D.) in healthy individuals. Subsequently, Freda et al. (19) reported an upper 
limit of nadir GH as $0.14 \mu \mathrm{g} / \mathrm{l}$ (means +2 s.D.), using a sensitive IRMA, in healthy adults. They also found that, in $50 \%$ of the active acromegalic patients with high IGF-I levels, GH was suppressed to less than $1 \mu \mathrm{g} / \mathrm{l}$, between 0.33 and $1 \mu \mathrm{g} / \mathrm{l}$. As recently reported by Dimaraki et al. (20) the difficulty is not only in the post-treatment disease activity decision but also in the diagnosis of acromegalics with biochemically mild disease. In their study, they found GH suppression to less than $1 \mu \mathrm{g} / \mathrm{l}$ in $50 \%$ of newly diagnosed acromegalic patients who had elevated IGF-I levels. When they used their upper normal limit of $0.21 \mu \mathrm{g} / \mathrm{l}$ they found abnormal GH suppression in all but one patient.

Our findings also suggest a sex difference in the suppression of GH after OGTT in healthy subjects. We found higher basal GH levels and a greater fall in $\mathrm{GH}$ from baseline in women than in men. However, when we evaluated $\mathrm{GH}$ suppression in different age groups this sex difference was only observed in the third decade. Therefore we suggest that there is no need for separate OGTT criteria for remission in female and male acromegalic patients. Although Chapman et al. (18) previously reported a sex difference, Freda et al. $(19,28)$ could not find a significant gender difference in the nadir GH levels of healthy subjects.

These earlier results, taken together with ours, suggest that a new cut-off value should be defined. But what should this value be? Very recently, Trainer (29) initiated a debate on this topic and proposed $0.3 \mu \mathrm{g} / \mathrm{l}$ as the cut-off value for the diagnosis and post-treatment remission decision in acromegaly based on data obtained from Freda et al. (28) and Dimaraki et al. (20). Then Freda (30) also proposed the same cut-off value. The present study showed that $95 \%$ of healthy subjects will have nadir GH levels less than $0.26 \mu \mathrm{g} / \mathrm{l}$ and IGF-I levels seem to correlate better with the nadir GH cut-off value of $0.26 \mu \mathrm{g} / \mathrm{l}$ than $1 \mu \mathrm{g} / \mathrm{l}$ in the determination of the disease activity of acromegaly. On the other hand, a minority of healthy subjects can have nadir $\mathrm{GH}$ levels up to $0.4 \mu \mathrm{g} / \mathrm{l}$ and, despite a normal GH suppression, some patients can still have elevated IGF-I levels. Therefore, the results should always be evaluated in conjunction with ageadjusted IGF-I levels. But it should also be kept in mind that age-related normal IGF-I levels vary considerably and in fact there are no standard reference ranges. Patients with high-for-age IGF-I levels but with normal glucose-suppressed $\mathrm{GH}$ levels should be followed more closely.

In conclusion, our data indicated that currently used criteria for remission including basal GH levels of less than $2.5 \mu \mathrm{g} / \mathrm{l}$ and a normal upper limit of $1 \mu \mathrm{g} / \mathrm{l}$ for $\mathrm{GH}$ after oral glucose do not discriminate between active and inactive patients with acromegaly. If the goal of the treatment is the normalization of $\mathrm{GH}$ and/or IGF-I levels, one should decide what the normal is. It seems that the accepted GH suppression levels after oral glucose are much higher than they should be, but this must be confirmed. On the other hand, it should be kept in mind that any desire to adopt aggressive GH and IGF-I criteria for remission may increase the risk of associated hypopituitarism and mortality per se. It seems that new epidemiologic mortality studies, using new criteria proposed by the present and previous studies, are needed for defining the safe cut-off values.

\section{Acknowledgements}

Part of this study was presented as a poster at the European Neuroendocrine Association Meeting, 1113 September 2002 in Munich, Germany and part at the Sixth European Congress of Endocrinology, 2930 April 2003 in Lyon, France.

\section{References}

1 Thorner MO, Vance ML, Edward RL Jr, Horvath E \& Kovacs K. The anterior pituitary. In Williams Textbook of Endocrinology, edn 9, ch. 9, pp 249-340. Eds JD Wilson, DW Foster, MH Kronenberg \& PR Larsen. Philadelphia: WB Saunders Company, 1998.

2 Arafah BM, Brodkey JS, Kaufman B, Velasco M, Manni A \& Pearson $\mathrm{OH}$. Transsphenoidal microsurgery in the treatment of acromegaly and gigantism. Journal of Clinical Endocrinology and Metabolism $1980 \mathbf{5 0}$ 578-585.

3 Freda PU, Wardlaw SL \& Post KD. Long-term endocrinological follow-up evaluation in 115 patients who underwent transsphenoidal surgery for acromegaly. Journal of Neurosurgery $1998 \mathbf{8 9}$ 353-358

4 Biermasz NR, Dulken HV \& Roelfsema F. Ten-year follow-up results of transsphenoidal microsurgery in acromegaly. Journal of Clinical Endocrinology and Metabolism $2000854596-4602$.

5 Barrande G, Lungo MP, Coste J. Ponvert D, Bertagna X, Luton JP et al. Hormonal and metabolic effects of radiotherapy in acromegaly: long-term results in 128 patients followed in a single center. Journal of Clinical Endocrinology and Metabolism $2000 \mathbf{8 5}$ 3779-3785.

6 Kreutzer J, Vance ML, Lopes MBS \& Laws ER Jr. Surgical management of GH-secreting pituitary adenomas: an outcome study using modern remission criteria. Journal of Clinical Endocrinology and Metabolism $2001864072-4077$.

7 De P, Rees DA, Davies N, John R, Neal J, Mills RG et al. Transsphenoidal surgery for acromegaly in Wales: results based on stringent criteria of remission. Journal of Clinical Endocrinology and Metabolism $2003 \mathbf{8 8} 3567-3572$.

8 Daughaday WH. New criteria for evaluation of acromegaly. New England Journal of Medicine 1979301 1175-1176.

9 DeMoranville BMC \& Jackson IMD. Diagnosis and endocrine testing in acromegaly. Endocrinology and Metabolism Clinics of North America 199221 649-668.

10 Anonymous, Consensus statement: benefits versus risks of medical therapy for acromegaly. Acromegaly Therapy Consensus Development Panel. American Journal of Medicine 199497 468-473.

11 Lamberts SWJ. Acromegaly and its treatment. Journal of Endocrinology 1997155 (Suppl 1) S23-S51 discussion S67-S71.

12 Melmed S, Jackson I, Kleinberg D \& Klibanski A. Current treatment guidelines for acromegaly. Journal of Clinical Endocrinology and Metabolism $1998 \mathbf{8 3} 2646-2652$.

13 Giustina A, Barkan A, Casanueva FF, Cavagnini F, Frohman L, Ho K et al. Criteria for cure of acromegaly: a consensus statement. 
Journal of Clinical Endocrinology and Metabolism $2000 \mathbf{8 5}$ $526-529$.

14 Bates AS, Van't Hoff W, Jones JM \& Clayton RN. An audit of outcome of treatment of acromegaly. Quarterly Journal of Medicine $199386293-299$.

15 Costa ACF, Rossi A, Martinelli CE Jr, Machado HR \& Moreira AC. Assessment of disease activity in treated acromegalic patients using a sensitive GH assay: should we achieve strict normal GH levels for a biochemical cure? Journal of Clinical Endocrinology and Metabolism 200287 3142-3147.

16 Holdaway IM, Rajasoorya CR, Gamble GD \& Stewart AW. Longterm treatment outcome in acromegaly. Growth Hormone and IGF Research 200313 185-192.

17 Hattori N, Shimatsu A, Kato Y, Koshiyama H, Ishikawa Y, Assadian $\mathrm{H}$ et al. Growth hormone responses to oral glucose loading measured by highly sensitive enzyme immunoassay in normal subjects and patients with glucose intolerance and acromegaly. Journal of Clinical Endocrinology and Metabolism $199070771-776$.

18 Chapman IM, Hartman ML, Straume M, Johnson ML, Veldhuis JD \& Thorner MO. Enhanced sensitivity growth hormone (GH) chemiluminescence assay reveals lower postglucose nadir $\mathrm{GH}$ concentrations in men than women. Journal of Clinical Endocrinology and Metabolism $1994 \mathbf{7 8} 1312-1319$.

19 Freda PU, Post KD, Powell JS \& Wardlaw SL. Evaluation of disease status with sensitive measures of growth hormone secretion in 60 postoperative patients with acromegaly. Journal of Clinical Endocrinology and Metabolism $1998 \mathbf{8 3} 3808-3816$.

20 Dimaraki EV, Jaffe CA, DeMott-Friberg R, Chandler WF \& Barkan AL. Acromegaly with apparently normal GH secretion: implications for diagnosis and follow-up. Journal of Clinical Endocrinology and Metabolism 200287 3537-3542.

21 Orme SM, McNally RJ, Cartwright RA \& Belchetz PE. Mortality and cancer incidence in acromegaly: a retrospective cohort study. United Kingdom Acromegaly Study Group. Journal of Clinical Endocrinology and Metabolism $1998 \mathbf{8 3} 2730-2734$.
22 Abosch A, Tyrrell B, Lamborn KR, Hannegan LS, Applebury CB \& Wilson CB. Transsphenoidal microsurgery for growth hormone secreting pituitary adenomas: initial outcome and long-term results. Journal of Clinical Endocrinology and Metabolism $1998 \mathbf{8 3}$ $3411-3418$

23 Swearingen B, Barker FG II, Katznelson L, Biller BM, Grinspoon S et al. Long term mortality after transsphenoidal surgery and adjunctive therapy for acromegaly. Journal of Clinical Endocrinology and Metabolism $1998 \mathbf{8 3} 3419-3426$.

24 Rajasoorya C, Holdaway IM, Wrightson P, Scott DJ \& Ibbertson HK. Determinants of clinical outcome and survival in acromegaly. Clinical Endocrinology 1994 495-102.

25 Serri O, Somma M, Comtois R, Rasio E, Beauregard H, Jilwan N et al. Acromegaly: biochemical assessment of cure after long term follow-up of transsphenoidal selective adenomectomy. Journal of Clinical Endocrinology and Metabolism 19856 1185-1189.

26 Beauregard C, Truong U, Hardy J \& Serri O. Long-term outcome and mortality after transsphenoidal adenomectomy for acromegaly. Clinical Endocrinology 200358 86-91.

27 Melmed S. Editorial: Tight control of growth hormone: an attainable outcome for acromegaly treatment. Journal of Clinical Endocrinology and Metabolism 199883 3409-3410.

28 Freda PU, Landman RE, Sundeen RE \& Post KD. Gender and age in the biochemical assessment of cure of acromegaly. Pituitary 20014 163-171.

29 Trainer PJ. Editorial: Acromegaly - consensus, what consensus? Journal of Clinical Endocrinology and Metabolism $2002 \mathbf{8 7}$ 3534-3536.

30 Freda PU. Current concepts in biochemical assessment of the patient with acromegaly. Growth Hormone and IGF Research $200313171-184$.

Received 29 August 2003

Accepted 11 December 2003 